\title{
DISCLOSURE OF CORPORATE SOCIAL RESPONSIBILITY (CSR) AND ITS EFFECT TO THE FINANCIAL PERFORMANCE OF SHARIA BANKS IN INDONESIA
}

\author{
${ }^{1}$ MUTHIA ROZA LINDA, ${ }^{2}$ YOLANDAFITRI ZULVIA
}

\begin{abstract}
This study aims to determine the effect of CSR disclosure information in the annual report of Sharia banks in Indonesia to their financial performance as measured by profitability ratios. This research function as an input for the company in the long term, that CSR is not as a burden for the company, and through CSR, the financial the performance of the company described through profitability ratios has, in fact, increased. The analysis method used is structural equation modeling with WapPLS ver.4.0 program. The results showed that CSR disclosure had a positive and significant effect on the financial performance of Sharia bank in Indonesia with p-value $0.03<0.05$. Bank Muamalat and BNI Syariah are banks that have the highest average in CSR disclosure of companies. Furthermore, the dimensions often disclosed in corporate CSR of Sharia banks in Indonesia are energy, environmental, and product dimensions.
\end{abstract}

Keywords - Corporate Social Responsibility, Financial Performance

\section{INTRODUCTION}

The financial performance of a bank can describe the financial condition and the welfare of the bank at a certain period of time. This can be seen from the assessment of assets, debt, liquidity and so forth. Many indicators that can be used in analyzing the bank's financial performance is the profit levels obtained by the company (profitability). Profitability is the banks' ability in obtaining profit in a certain period. In this research, profitability level uses Return On Asset (ROA) ratio to see how far the ability of banks to generate profits derived from assets which funds mostly come from the public.

Various ways and strategies are developed by a company in an effort to increase its profits. One of the most prominent issues of the current global economy is sustainability (Isakson\&Steimle, 2009). Sustainability recognizes the importance of growth and profit gained by the company in line with the company's social goals (Wilson, 2003). CSR activity in Sharia Banking has basically been embedded internally as a consequence of Sharia banks' reliance on the teachings of Islam. The social activities of Sharia banks are an added value that can have implications for the increase in long-term profitability and goodwill gained from the positive image of the business, and an increased trust from the stakeholders on the performance of Sharia banks (Anto \& Astuti, 2008).

By focusing on the company's sustainability and financial reporting, there are many possible benefits that the company can achieve. Some of the advantages obtained by the company include an increase in employee satisfaction that can ultimately improve the efficiency and the profitability of the company (Thome, 2009: Giannarakis \& Theotokas, 2011; Tse, 2011). In addition, the company also benefits from the improvement of company's competitiveness and it will provide a better strategic corporate market positioning strategy (Pitelis \& Boulouta, 2011).

\section{LITERATURE REVIEW}

\section{A. Financial Performance}

The success of a company can be seen from its financial performance. Financial performance is a tangible result achieved by a business entity in a certain period of time that can reflect its financial health and can be used to indicate the achievement of positive results. To measure financial performance of Sharia banking, this research used profitability ratio. Profitability ratio is a ratio that measures the ability of a company to earn profits in relation to sales, total assets and its own capital. Munawir (2001) explains that profitability is used to measure the efficiency of capital use in a company by comparing profit with capital used during operations; therefore, large profits do not guarantee or is not a measure that the company is rentable. For the management or other parties, high profitability is more important than a big profit. Some commonly used profitability ratios, among others are:

\section{Return On Assets (ROA)}

ROA is the company's financial ratios related to profitability, and it measures the ability of the company to generate profits at a given level of revenue, assets and capital stock (Hanafi and Halim, 2003). By knowing ROA, we can assess whether the company has been efficient in using its assets and its operating activities to generate profits.

Formula:

$$
\text { ROA }=\frac{\text { Net Profit after Tax }}{\text { Total Assets }}
$$

\section{Return On Equity (ROE)}

ROE is a ratio that shows how far the company manages its own capital (net worth) effectively, and it measures the rate of return on investment that has been done by the owner of the capital itself or the 
shareholder of a company. ROE shows the rentabilty of the company's capital or which is often called business profitability (Sawir, 2009).

Formula:

$$
\text { ROE }=\frac{\text { Net Profit after Tax }}{\text { Equity }}
$$

\section{Gross Profit Margin (GPM)}

GPM is a ratio that measures the efficiency of cost control or cost of production, and it indicates the company's ability to produce efficiently (Sawir, 2009). GPM is the percentage of gross profit compared to sales. The bigger the GPM, the better the company's operating condition, because it shows that the cost of goods sold is relatively lower compared to sales, and vice versa. The lower the GPM, the less good the company's operation (Syamsuddin, 2009: 61).

\section{Formula:}

$$
G P M=\frac{\text { Net Sales }- \text { Cost of Goods Sold }}{\text { Net Sales }}
$$

\section{B. Corporate Social Responsibility}

CSR is a continuing commitment by the business community to act ethically and to contribute to the economic development of the local community or the wider community, along with improving the lives of its workers and their whole family (Wibisono, 2007: 7). Meanwhile, according to Company Law No. 40 of 2007 article one point three (2007: 2), Social and Environmental Responsibility (or CSR) is the company's commitment to participate in sustainable economic development in order to improve the quality of life and the environment that is beneficial for the company itself, the local community, and the society in general.

In addition, ISO 26000 on Guidance on Social Responsibility also provides a definition of CSR. According to ISO 26000 (draft 3, 2007) in Rista (2009), CSR is the responsibility of an organization for the effects of its decisions and activities on the society and the environment, which is embodied in the form of transparent and ethical behavior that is consistent with sustainable development and the community welfare, taking into account the expectations of stakeholders, and is in line with established laws and international behavior norms, and integrated with the organization as a whole. In short, corporate social responsibility (CSR) is the obligation of business organizations to take part in activities aimed at protecting and improving the welfare of society as a whole.

\section{Benefits of CSR}

According to Ernia (2015: 6), CSR can provide many benefits, among others:
1. increased profitability for the company and better financial performance.

2. reduce the risk of collision with surrounding communities.

3. able to improve the reputation of the company, which is also a part of corporate image building.

CSR will increase the profits of the company. The company will have better financial performance since many large companies that disclose CSR programs show a tangible advantage to the improvement of corporate financial performance. In addition, CSR can reduce the risk of collision with surrounding communities, because the real purpose of CSR is to strengthen the sustainability of the company itself in a certain area through the act of building cooperation among stakeholders who facilitate the company, and by preparing programs for the development of its surrounding community. In another word, CSR is the company's ability to adapt to its surrounding environment, community and related stakeholders. CSR is also able to improve the reputation of the company and this can be viewed as social marketing for the company. Social marketing will be able to provide benefits in the formation of a company's brand image in relation to the company's ability to commit to the preservation of environment in addition to having a high quality product. This will certainly have a positive impact on the volume of production units absorbed by the market which will ultimately bring huge profits to the increase of corporate profits. CSR activities aimed at improving this corporate context enables the alignment between social and business benefits for its long-term material and social benefits.

\section{Basic Components of CSR}

Elkington (1997), as cited by Hasibuan and Sedyono (2006: 73), mentions that CSR is divided into three main components, namely: people, profit, and the planet. These three components are now often used as the basis of planning, disclosure and evaluation (reporting) of CSR programs which are known as the triple bottom line. Meanwhile, Wibisono (2007: 32) argued that basically companies that want to be sustainable must adhere to the 3Ps; in addition to the pursuit of profit, companies must also pay attention to and engage in the fulfillment of people's welfare (people) and contribute actively in preserving the environment (planet).

Therefore, based on the above opinion, the company is no longer faced with the responsibility solely based on the single bottom line, which is the economic aspect reflected in its financial condition, but also must pay attention to the social and environmental aspects.

\section{E. CSR Indicators}

The CSR indicators used in this study used adapted indicators from Sembiring (2005). Later on, these 
CSR indicators were assessed using the Dummy variable. Dummy codes generally use a rating category denoted by 1 or 0 . The dummy 0 (zero) group is called the excluded group, while the dummy 1 group is called the included group (Ghozali 2006).

The dimensions of CSR disclosure based on Sembiring (2005) consist of:

1. The Environmental dimension, which consists of 6 items

2. Energy dimension, which consists of 3 items

3. Workplace Health and Safety dimension, which consists of 8 items

4. Employee dimension, which consists of 29 items

5. Products dimension, which consists of 6 items

6. The Community Involvement dimension, which consists of 11 items

The total dimensions consist of 63 items and each dimension contains better detail about the specific disclosure area and is marked using codes 0 or 1 . A value 0 is provided if no information is disclosed. A value of 1 is given if the company has done several activities that correspond to the coded category.

The independent variable in this research is CSR. The calculation of Corporate Social Responsibility Index (CSRI) is as follows:

$$
\operatorname{CSR} D_{j}=\frac{\Sigma x_{i j}}{N_{j}} \times 100 \%
$$

In which:

$\mathrm{CSRD}_{\mathrm{j}} \quad$ : CSR Disclosure Index of Company $\mathrm{j}$

$\mathrm{N}_{\mathrm{j}} \quad$ : number of items for Company $\mathrm{j}, \mathrm{n}_{\mathrm{j}} \leq 79$

$X_{\mathrm{ij}} \quad$ : dummy variable: $1=$ if item $\mathrm{i}$ is disclosed; $0=$ if item $\mathrm{i}$ is not disclosed

\section{F. Conceptual Framework}

Based on the theoretical basis, the results of previous research and the problems that have been put forward, the conceptual framework used as a basis for formulating the hypothesis and then formulated into the research model, is as follows:

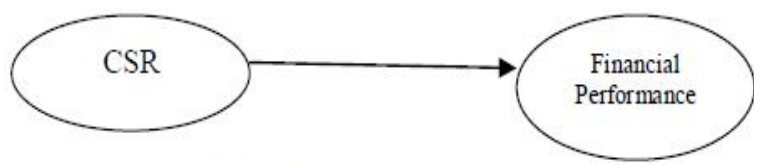

Figure 2.1. Conceptual Framework

\section{RESEARCH METHODS}

The type of research conducted is a casual associative design, which is a research that aims to analyze the relationship between one variable with another variable. The population used in this study is the Sharia Banks found in Indonesia which amounted to 11 Sharia banks during the year 2011-2016. The sample is the total population of 10 Sharia banks out of 11 Sharia banks in Indonesia and the data used is of the last 6 years data from each bank. The only bank not included in this research is BRI Syariah due to the bank's website inaccessibility.

\section{OPERATIONAL DEFINITION}

The exogenous variable in this study is CSR which is the obligation of business organizations to take part in activities that aim to protect and improve the welfare of society as a whole. The calculation of Corporate Social Responsibility Index (CSRI) is as follows:

$\operatorname{CSR} D_{j}=\frac{\Sigma x_{i j}}{n_{j}} \times 100 \%$

In which:

$\mathrm{CSRD}_{\mathrm{j}} \quad$ : CSR Disclosure Index of Company $\mathrm{j}$

$\mathrm{N}_{\mathrm{j}} \quad$ : number of items for Company $\mathrm{j}, \mathrm{n}_{\mathrm{j}} \leq 79$

$\mathrm{X}_{\mathrm{ij}} \quad$ : dummy variable: $1=$ if item $\mathrm{i}$ is

disclosed; $0=$ if item $\mathrm{i}$ is not disclosed

The endogenous variables in this study are financial performances which consist of:

$$
\begin{aligned}
\text { ROA } & =\frac{\text { Net Profit after Tax }}{\text { Total Assets }} \\
\text { ROE } & =\frac{\text { Net Profit after } T a x}{\text { Equity }} \\
\text { GPM } & =\frac{\text { Net Sales }- \text { Cost of Goods Sold }}{\text { Net Sales }}
\end{aligned}
$$

\section{METHOD OF ANALYSIS}

Data analysis method used to test the effect of CSR disclosure to the company's financial performance is the structural equation modeling. Data were processed by the main analysis tool, the equation structural equation modeling (SEM) -WrapPLS ver. 4.0. SEM WrapPLS is used because the PLS approach does not require data to be normally distributed and can be used on small samples. Based on the assumption of distribution free, PLS can handle all data formats, be it in time series or cross section (Ghozali, 2014: 6). The data in this research are panel data; thus, the analysis of PLS model with observed variables used the panel data with the help of WrapPLS program. No measurement model is needed to test the reliability and validity, so the structural modeling can be directly estimated.

\section{RESEARCH RESULT AND DISCUSSION}

Disclosure of Corporate Social Responsibility (CSR) based on CSR Index at Commercial Sharia Bank (BUS) in Indonesia

Based on the Corporate Social Responsibility Index (CSRI), CSR disclosures are grouped into several dimensions: the dimensions of environment, energy, workplace health and saftey, employee, products, and community involvement. CSR disclosure item recapitulation based on the CSRI of Commercial 
Disclosure of Corporate Social Responsibility (CSR) and Its Effect to the Financial Performance of Sharia Banks in Indonesia

Sharia Bank in Indonesia period 2011-2016 can be seen in table below:

\begin{tabular}{|l|l|l|l|l|l|l|l|l|}
\hline No & Name of Bank & $\mathbf{2 0 1 1}$ & $\mathbf{2 0 1 2}$ & $\mathbf{2 0 1 3}$ & $\mathbf{2 0 1 4}$ & $\mathbf{2 0 1 5}$ & $\mathbf{2 0 1 6}$ & Mean \\
\hline 1 & Muamalat & $49,21 \%$ & $44,44 \%$ & $46,03 \%$ & $31,75 \%$ & $31,75 \%$ & $41,27 \%$ & $40,74 \%$ \\
\hline 2 & BCA Syariah & $25,40 \%$ & $46,03 \%$ & $31,75 \%$ & $19,05 \%$ & $22,22 \%$ & $19,05 \%$ & $27,25 \%$ \\
\hline 3 & BJB Syariah & $36,51 \%$ & $33,33 \%$ & $39,68 \%$ & $28,57 \%$ & $19,05 \%$ & $23,81 \%$ & $30,16 \%$ \\
\hline 4 & BNI Syariah & $28,57 \%$ & $42,86 \%$ & $44,44 \%$ & $28,57 \%$ & $34,92 \%$ & $39,68 \%$ & $36,51 \%$ \\
\hline 5 & Bukopin Syariah & $34,92 \%$ & $36,51 \%$ & $39,68 \%$ & $26,98 \%$ & $20,63 \%$ & $25,40 \%$ & $30,69 \%$ \\
\hline 6 & Mandiri Syariah & $34,92 \%$ & $44,44 \%$ & $39,68 \%$ & $36,51 \%$ & $26,98 \%$ & $34,92 \%$ & $36,24 \%$ \\
\hline 7 & Maybank Syariah & $19,05 \%$ & $33,33 \%$ & $38,10 \%$ & $33,33 \%$ & $23,81 \%$ & $28,57 \%$ & $29,37 \%$ \\
\hline 8 & Mega Syariah & $23,81 \%$ & $39,68 \%$ & $36,51 \%$ & $23,81 \%$ & $19,05 \%$ & $22,22 \%$ & $27,51 \%$ \\
\hline 9 & Panin Syariah & $23,81 \%$ & $31,75 \%$ & $33,33 \%$ & $22,22 \%$ & $22,22 \%$ & $26,98 \%$ & $26,72 \%$ \\
\hline 10 & Victoria Syariah & $20,63 \%$ & $15,87 \%$ & $20,63 \%$ & $23,81 \%$ & $23,81 \%$ & $26,98 \%$ & $21,96 \%$ \\
\hline
\end{tabular}

Table 1. Disclosure of Corporate Social Responsibility based on CSRI at Commercial Sharia Bank In Indonesia Year 2011-2016 Source: Processed data (2017)

Table 3 shows that the disclosure of CSR by Sharia banks in Indonesia fluctuate every year. The highest peak of CSR disclosure by the company is in 2012, but after 2012, CSR disclosure has a trend that tends to decline until 2015, including Mega Syariah Bank, which disclosure of CSR declined every year. Although almost all banks experiences a decrease in their CSR disclosure until 2015, only one bank in 2015 still experienced an increase in the disclosure of its CSR, the bank BNI Syariah. From the decline in CSR disclosure made by the company, Muamalat bank has the highest average CSR disclosure, followed by BNI Syariah. It shows that the concern of Muamalat bank and BNI Syariah bank is more towards greater social responsibility than other Sharia banks when viewed using CSR Index. The least bank with CSR disclosure is Victoria Syariah bank. CSR disclosure based on CSRI at Sharia Banks in Indonesia is not yet complete. This is due to some items that are not possible to be met by the banking industry, especially by Sharia banking. In general, many dimensions published by banks include; environmental, energy, workplace health and safety, employee, products, and community dimensions.

\begin{tabular}{|l|l|l|l|l|l|l|l|}
\hline CSR Dimensions & $\mathbf{2 0 1 1}$ & $\mathbf{2 0 1 2}$ & $\mathbf{2 0 1 3}$ & $\mathbf{2 0 1 4}$ & $\mathbf{2 0 1 5}$ & $\mathbf{2 0 1 6}$ & Mean \\
\hline Environment & $41,67 \%$ & $38,33 \%$ & $43,33 \%$ & $38,33 \%$ & $35,28 \%$ & $35,56 \%$ & $38,75 \%$ \\
\hline Energy & $41,67 \%$ & $53,33 \%$ & $46,67 \%$ & $46,67 \%$ & $34,44 \%$ & $55,56 \%$ & $46,39 \%$ \\
\hline $\begin{array}{l}\text { Workplace Health and } \\
\text { Safety }\end{array}$ & $20,00 \%$ & $35,00 \%$ & $35,00 \%$ & $25,00 \%$ & $20,16 \%$ & $25,31 \%$ & $26,74 \%$ \\
\hline $\begin{array}{l}\text { Employee) Fringe } \\
\text { Benefits }\end{array}$ & $27,60 \%$ & $32,41 \%$ & $33,10 \%$ & $21,38 \%$ & $17,65 \%$ & $21,09 \%$ & $25,54 \%$ \\
\hline Products & $36,63 \%$ & $50,00 \%$ & $41,67 \%$ & $31,67 \%$ & $27,22 \%$ & $27,22 \%$ & $35,74 \%$ \\
\hline Community & $28,23 \%$ & $37,27 \%$ & $40,00 \%$ & $31,82 \%$ & $21,16 \%$ & $23,88 \%$ & $30,39 \%$ \\
\hline
\end{tabular}

Source: Processed data (2017)

Tabel 2. CSR Disclosure for Each Dimension

The table above shows that the dimensions often disclosed by the CSR of Sharia banks in Indonesia are the energy, environmental, and products dimensions. The dimensions that have little disclosure is the dimensions of employee and workplace health and safety.

\section{WrapPLS Analysis}

SEM WrapPLS is used because the PLS approach does not require the data to be normally distributed, and can be used on small samples. Based on the assumption of distribution free, PLS can handle all data formats whether they are in time series or cross section (Ghozali, 2014: 6). The data in this research is panel data; thus, the analysis of PLS model with variable observed used the panel data with the help of WrapPLS program. This model did not need to go through measurement model to test itsreliability and validity, so the structural model estimation was done directly. From the analysis of the WrapPLS, the following research results are obtained: 


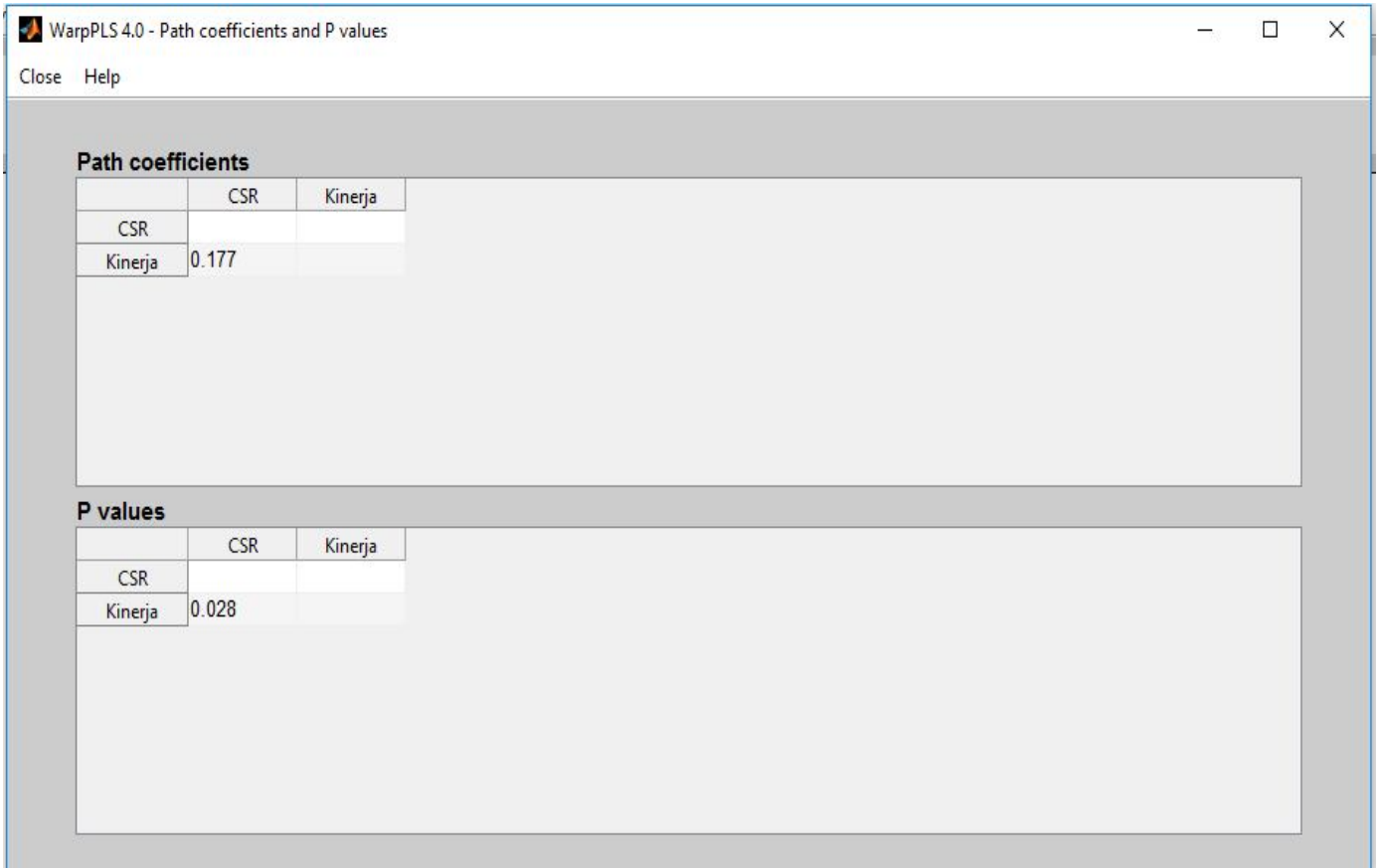

Source: Processed data (2017)

Based on the results of the table above, it can be seen that the CSR has a significant effect on the performance with the value of P-Value $0.028<0.05$. It can be concluded that CSR disclosure of the company affected the financial performance of the company. The illustration on the influence of CSR on the financial performance of the company can be seen in the table below.

\begin{tabular}{|l|l|}
\hline & Kinerja \\
\hline R-Squared & 0.031 \\
\hline Q-Squared & 1.032 \\
\hline Full Collin. VIF & 0.031 \\
\hline
\end{tabular}

Tabel 4. Latent Variable Coefficient

Source: Processed data (2017)

From the table above, it can be seen that the value of $\mathrm{R}$-Square of the company performance variable is 0.031 . This means that the value belongs to the small category and the variation that can be explained by CSR is only 3.1\%. Q-Squared value generated model $0.031>0$ means that the model has predictive validity. A full collinearity VIF value of $1.031<3.3$ means that there is no collinearity problem in the PLS model. And the model is declared as fit because the value of Average Path Coefficient (APC) is 0.014 $<0.05$. Since the purpose of this SEM analysis is only to test the hypothesis, the evaluation of the fit model is less important. On the contrary, if the purpose of the analysis is to find a fit model with the original data, the evaluation of the fit model becomes important and useful for measuring the quality of the model (Ghozali, 2014: 101). This is in accordance to what has been suggested by Hair et al. (2012: 332) and Henseler and Sarstedt (2013), who state that the calculation of the goodness of fit (GoF) model with formative constructs is not recommended to be applied. The structural image of this research model is as follows:

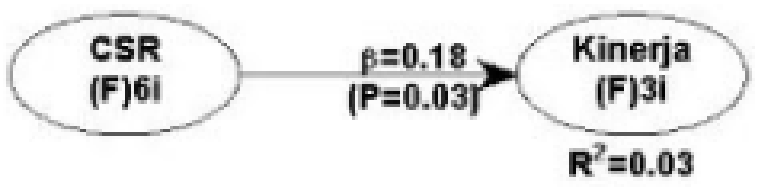

Figure 1. Structural Model

\section{DISCUSSION}

Disclosure of CSR activities in the annual report may attract investors or stakeholders to invest in the company. By conducting CSR activities, the company shows that it operates not only for its own sake, but it still provides benefits for stakeholders for covering social and environmental responsibility activities.

Disclosure of CSR is a key corporate strategy that cannot be separated within the company (Ismail, 2009). Disclosure of CSR in the annual report is a way for the company to build, maintain, and legitimize the contribution of the company from the economic and political sides (Ismail, 2009).

Heal and Gareth (2004) argue that CSR activities can be a beneficial element in corporate strategy, contributing to risk management and maintaining relationships that can provide long-term benefits for the company. One of the expected benefits of disclosure of CSR activities is the enhancement of corporate reputation in the eyes of stakeholders who can attract investors to invest in the company. With more and more investors interested in investing, the funds owned by the company to perform operational activities will be greater and better the company's financial performance. 
McGuire et al. (1998), in Balabanis, Phillips, and Lyall (1998) explains that the company's reputation proves to be enhanced by CSR activities, and it improves its relationships with banks, investors, and government agencies, and those relationships are reflected in the financial benefits of the company. This will trigger the company's finances to be better so that the company's earnings will increase. This condition will be reflected in the comany's financial performance next year.

The results of this study are in line with the results of research by Mahoney and Robert (2003), in which there is a positive and significant relationship between social performance, corporate environment and the company's performance. Also, the results of research conducted by Tsoutsoura (2004) in which social responsibility has a significant effect on profitability is reflected in the ROA.

\section{CONCLUSIONS AND SUGGESTIONS}

\section{CONCLUSION}

Based on the results of data analysis that has been done, it can be concluded that:

1. Disclosure of CSR has a positive and significant impact on financial performance at Sharia commercial banks in Indonesia with p-value of $0.03<0.05$.

2. Muamalat Bank and BNI Syariah are the banks that have the highest average in CSR corporate disclosure.

3. Dimensions often disclosed in corporate CSR by sharia banks in Indonesia are energy, environmental dimensions, and product dimensions.

\section{SUGGESTIONS}

Based on the results of research that has been obtained, it is recommended that:

1. The disclosure of financial statements in accordance with the operational activities of the sharia banking industry should be evaluated properly by each indicator.

2. To obtain better results of research, further research may extend the study period.

\section{REFERENCES}

[1] Anto and Astuti. 2008. Persepsi Stakeholder Terhadap Pelaksanaan Corporate Social Responsibility : Kasus Padan Bank Syariah di DIY. Jurnal Akuntansi: 10 (1) : $19-30$

[2] Balabanis, Phillips, and Lyall. 1998. Corporate Social Responsibility and Economic Performance in The Top British
Companies: Are They Linked?. European Business Review, Vol.98, No. 1

[3] Ghazali. 2006. Aplikasi Analisis Multivariate Dengan Program SPSS. Semarang: Universitas Diponegoro.

[4] Ghazali. 2014. Partial Least Squares. Konsep, Metode dan Aplikasi Menggunakan Program WarpPLS 4.0. Semarang: Universitas Diponegoro.

[5] Giannarakis, G and Theotokas. 2011. The Effect Of Financial Crisis In Corporate Social Responsibility Performance. International Journal Of Marketing Studies Vol.3

[6] Hanafi, Mamduh dan Abdul Halim. 2003. Analisis Laporan Keuangan. Edisi Revisi. Yogyakarta: UPP AMP YKPN.

[7] Hasibuan dan Sedyono. 2006. CSR Communication: A Challenge On Its Own, Economics Business Accounting Review. Edisi III. September-Desember 2006.

[8] Heal, Geoffrey, dan Garret, Paul. 2004. "Corporate Social Responsibility, An Economic and Financial Framework",Columbia Bussiness School.

[9] Henseler, J. and M. Sarstedt. 2013. Goodness-of-fit indices for partial least squares path modeling. Computational Statistics, 28(2), 565-580.

[10] Isakson, Raine and Steimle, Ulrich. 2009. What does GRIreporting tell us about corporate sustainability? The TQM Journal, Vol. 21(2):168-181.

[11] Mahoney, Lois dan Robin Robert. 2003. Corporate Social and Environmental Performance and Their Relation to Financial Performance and Institutional Ownership: Emperical Evidence on Canadian Firms. http://www.accounting.rutgers.edu.

[12] Munawir, S. 2001. Akuntansi Keuangan dan Manajemen. Edisi Pertama. Jogjakarta: BPFE.

[13] Pitelis, C and Boulouta, I. 2011. CSR- Based Positioning Strategies, National Competitive Advantage And The Role Of Innovation.

[14] Ernia Christy Rahayu. 2015. Dampak Kinerja Keuangan dan Pengungkapan Corporate Social Responsibility Terhadap Nilai Perusahaan. Jurnal Ilmu dan Riset Akuntansi. Vol. 4, No. 3

[15] Rista, 2009. Corporate Social Responsibility dalam Praktik di. Indonesia. Edisi 1, Jakarta: Penerbit Elex Media Computindo.

[16] Sawir, Agnes. 2009. Analisa Kinerja Keuangan dan Perencanaan Keuangan Perusahaan. Jakarta: PT. Gramedia Pustaka Utama.

[17] Sembiring. 2005. Karakteristik Perusahaan dan Pengungkapan Tanggung Jawab Sosial: Study Empiris pada Perusahaan yang tercatat di Bursa Efek Jakarta.Simposium Nasional Akuntansi 8.

[18] Ismail, Solihin. 2009. Corporate Social Responsibility from Charity to Sustainability. Jakarta : Salemba Empat.

[19] Syamsuddin. 2009. Manajemen Keuangan Perusahaan. Jakarta: PT. Raja Grafindo Persada.

[20] Tsoutsoura, Margarita, 2004. "Corporate Social Responsibility and Financial Performance," Haas School of Business University of Calofornia at Berkeley

[21] Thome, F. 2009. Corporate Responsibility In The Age Of Irresponsilibity: A Symbiotic Relationship Between CSR And The Financial Crisis. International Institute For Sustainable Development

[22] Tse, T. 2011. Shareholder And Stakeholder Theory. After The Financial Crisis. Qualitative Research In Financial Markets Vol. 3 No.3 No.1 51-63

[23] Wibisono. 2007. Membedah Konsep dan Aplikasi Corporate Social Responsibility. Surabaya: Media Grapka.

[24] Wilson Mel (2003). Corporate sustainability: What is it and where does it come from? Ivey Bus. J. Jul/Aug2003. 67(6): 15

[25] Undang-Undang Perseroan Terbatas No. 40 Tahun 2007 


\title{
ANALYSIS OF FINANCIAL LITERACY AND FINANCIAL INCLUSION AS A STRATEGY TO IMPROVE THE COMPETITIVENESS OF SMALL-MEDIUM ENTERPRISES (SMES) OF HANDICRAFTS BUSINESS IN WEST SUMATERA
}

\author{
${ }^{1}$ ROSYENI RASYID, ${ }^{2}$ ERNI MASDUPI, ${ }^{3}$ YASRI, ${ }^{4}$ MUTHIA ROZA LINDA \\ Universitas Negeri Padang,Indonesia \\ E-mail: muthia_rozalinda@yahoo.com
}

\begin{abstract}
The handicraft industry is one of top selling industries in West Sumatera. The industry also brings considerable contribution to the wealth of the community. In general, the main problem in the handcraft industry is on its capital and marketing. The objective of this study are to find the level of financial literacy and financial inclusion of the handicraft entrepreneurs, as well as to see the correlation between the level of financial literacy with the level of financial inclusion, and to identify the factors that hinder the development of financial inclusion. This research used field observations, interviews, and distribution of questionnaires as its primary data, and the secondary data were obtained from related agencies. To answer the research question, we used descriptive analysis method and structural equation modelling. The results show that the financial literacy has a positive and significant impact on the financial inclusion of the handicraft entrepreneurs, the level of financial literacy of the sample is categorized as sufficiently literate, and the financial inclusion of the handicraft entrepreneur is also categorized as sufficient. Therefore, it will be necessary to develop the financial inclusion by overcoming the obstacles faced by SMEs, especially in accessing banking services and other formal financial institutions in order to improve the competitiveness of SMEs.
\end{abstract}

Keyword - Financial Literacy, Financial Inclusion, handicraft SMEs.

\section{INTRODUCTION}

In order to create more equal, participatory, and inclusive economic growth, factual efforts are needed to encourage economically productive activities. One of productive economy sectors that needs to be developed is small and medium enterprises (SMEs). SMEs play a big role in stimulating the economic growth in various regions in Indonesia. The number of SMEs in Indonesia is higher than the number of large entreprises, reaching up to $99.99 \%$ of the market share (Kemenkop, 2013). SMEs are able to sustain and enliven the economy of a region and could highly contribute to the economic welfare for each family head in the neighborhood. However, the SMEs could not be separated from conditions that hinder their growth. There are various types of SMEs in Indonesia; one of them is the handicraft SMEs. The conditions encountered by the SMEs are not entirely ideal. The result of a survey conducted by the World Bank team in 2014 shows the description of difficulties encountered by the handicraft SMEs in Indonesia in running their business. The difficulties are described as follows: (Bank Indonesia, 2015)
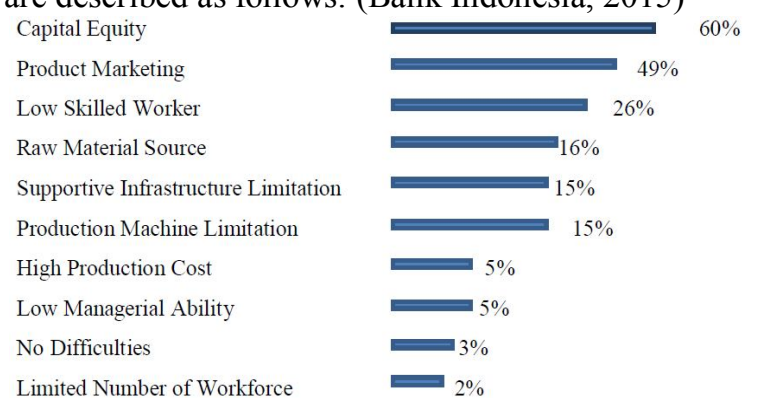

Source: Survey processed by World Bank Team (2014)

Based on the survey above, it is shown that in running their business, the biggest difficulties experienced by handicraft business player are the problem of capital, marketing, and human resource skills. Generally, the source of the capital for the handicraft business only comes from personal equity or from personal or family funds. This indicates the low level of financial inclusion of the SME handicraft managers. Therefore, a program or a model of financial inclusion is required to accelerate the access of SMEs to formal financial services in their regions.

The West Sumatra economy is still supported by small and medium enterprises (SMEs). This could be seen from the composition of its business sector which is still dominated by $84 \%$ of micro business, followed by $14 \%$ of small business sector, and only around $1.5 \%$ of medium business; it could be said that there is no large scale industry (Hap, 2017). Therefore, an effort in development of SME is needed to improve the wealth of community in West Sumatra.

One of the top selling products that become dominant in West Sumatra is the craft of embroidery, weaving, silver handicrafts, and furnitures. However, in its development, these business still encounter several obstacles. The main obstacle in developing the handicraft industry SMEs is in terms of capital and marketing (Rashid, 2016). To develop a business unit, capital is the main factor needed. In general, the source of capital in the craft business only comes from personal equity or from personal or family 

of Handicrafts Business in West Sumatera

funds. Based on the research on 60 business players of embroidery in Padang, West Sumatera, the composition of funding resource of the craft business amounted to as much as $47 \%$ entrepreneurs used $100 \%$ personal capital which comes from personal savings of the entrepreneurs themselves, family and friends' support, $45 \%$ used a small amount of debt, and only $8 \%$ of entrepreneurs used bank loans in their capital composition (Rashid, 2016). This indicates that there is a lack of access to financial institutions among the handicraft businessmen in Padang.

Several things that become the obstacles for the community to access formal finance systems include: the lack of knowledge, high costs, non-price obstacles such as administrative issues and behavioral issues, such as community perceptions towards banks (Sachindra, 2013). Others argue that the factors that hinder the public access to the formal financial sectors can be grouped into two categories of the demand side and the supply side. Demand-side barriers are caused by the community's lack of knowledge and lack of awareness towards financial services, low incomes, and lack of financial and social security. The barriers from the supply-side are the distance of access from the people's residence to the bank, complicated procedures, incompatibility of the existing financial products with the entrepreneurs' needs, the use of less understood language toward customers, the bank employees' behavior, and inflexibility of the bank's operation time (Rakhmindyarto \& Syaifullah, 2013). Meanwhile, according to the governor of Bank Indonesia, one of the factors that cause lack of access to financial institutions on the SMEs is the low level of financial literacy of the SMEs. In general, the SMEs knowledge is limited on banking service, and they tend to be less conscious of the financial products offered by other financial institutions, so that their funding only relies on the financing service of manual and conventional bank. This condition could decrease the development of SMEs, since the SMEs development will be in line with the level of financial literacy and the proximity of SMEs to financial access (Soepardi, 2016)

The limited access of the handicrafts SMEs towards the formal financial sector are caused by several obstacles, which are generally grouped into two categories: demand barriers and supply barriers. This study is conducted to find the level of financial literacy and the implementation of financial inclusion of the handicraft's business player, as well as factors that hinder the handicraft SMEs' access to financial institutions. The objectives of this study is to determine the level of financial literacy of the handicraft SMEs and its correlation with the application of financial inclusion, and to find out the factors that hinder the access of crafts SMEs to financial institutions. In the future, the result of this study could help in finding the right model for the development of the financial inclusion as a strategy to increase the competitiveness of handicrafts SMEs in West Sumatra.

\section{LITERATURE REVIEW}

\section{A. Financial Literacy}

A businessman should possess the ability to plan, execute and control the financial management of his business. He must also be able to make decisions effectively and efficiently, so that his business could produce maximum profit. To make an effective and efficient financial decision, a businessperson must have the knowledge in financial management, and this ability is known as financial literacy.

There are several definitions of financial literacy. The Financial Services Authority Agency (2013) states that financial literacy is the ability to manage the funds to grow and to live more prosperously in the future. A person's financial literacy can be measured from his basic knowledge about the concept of financial investment, such as inflation and risk, as well as the ability to perform interest rates calculations. Financial literacy is the ability to manage finances in order to live more prosperously in the future (Chen \& Volpe, 1998). Financial literacy includes concepts ranging from awareness and knowledge about financial products, financial institutions, and concepts about financial skills $(\mathrm{Xu}$, Lisa, Zia, \& Bilal, 2012). Financial literacy can also be defined as a measurement on how well a person can understand and use the financial information (Huston, 2010). Financial literacy not only requires the knowledge dimension, but also requires an additional dimension, i.e the application which requires a person's ability and his confidence to use his financial knowledge in financial decision-making. Good financial literacy will enhance entrepreneurs' ability in financial management and in making the right decisions for their companies (Muraga \& John, 2015). Financial literacy covers several aspects of finance: basic knowledge of personal finance, money management, credit and debt management, savings and investment, and risk management. Thus, financial literacy can be measured using four indicators: basic knowledge of financial management, credit management, savings and investment management, risk management (Chen \& Volpe, 1998).

Based on the national strategy of Indonesian financial literacy, the public financial literacy is classified into 4 levels, namely: 1) Well Literate: having knowledge and belief on financial service institutions and financial products and services, including features, benefits and risks, rights and obligations related to financial products and services, and posses skills in using financial products and services. 2) Sufficiently Literate: possesses knowledge and belief about financial services institutions as well as the financial products and services, including features, benefits and 
risks, rights and obligations related to financial products and services. 3) Less Literate: only possess knowledge of financial services institutions, financial products and services. 4) Not Literate: does not possess any knowledge and belief about financial services institutions and financial products and services, and does not have skills to use financial products and services (Sugiarto, 2013).

There are many researches who studied the factors that influence the public financial literacy. In general, the applied factors are the demographic factors. Demography is a description about a person's background that influences his financial literacy (Mandel, 2008). Demographic factors include age, sex, family status, migration status, education level, occupation, residence and regional area (Keown \& Anne, 2011). They could also consist of parents' education level, allowance, education level and faculty, parent's income and insurance (Nidar \& Bestari, 2012). Another demographic factors that affect financial literacy are age, sex, education level, number of children, marital status and work experience (Mahdzan, Shahnaz, Tabiani, \& Saleh, 2013).

\section{B. Financial Inclusion}

Financial inclusion is an effort to encourage the financial system to be accessible to any level of society. According to the Financial Services Authority, Financial Inclusion is efforts aimed at eliminating any obstacles, both price and non-price, for the public to access the use of financial services and to provide significant benefits to improve the living standards of society (Alamsyah, 2014 ). There are several factors that cause the need for inclusion, namely; (a) inability to access financial services that may result in the exclusion of financial entities to obtain capital, and (b) lack of access towards safe and formal savings that may reduce their motivation to save. The formal savings pose as security benefit and increase interest rates (Shankar, 2013).

Performance measurement is required to find out how far the development of financial inclusion activities is. Several indicators to measure the development of financial inclusion of a country are: 1) Availability / access, to measure the ability to use formal financial services, in terms of physical and price affordability, 2) Usage, to measure the ability of the actual use of financial products and services. 3) Quality, to measure whether the attributes of financial products and services have met the needs of customers, and 4) Welfare, to measure the impact of financial services on the level of users' life (Setiawan, 2015).

\section{Small and Medium Enterprises (SMEs)}

Small and Medium Enterprises (SMEs) has been regulated in Act Number 20 Year 2008 of the Republic of Indonesia, and is defined as any legal business activity which existence could provide new jobs for society, and have the roles to equalize and increase the community incomes, stimulates the economic growth and achieve the national stability (Law No. 20, 2008).

Based on Article 2 of Act no. 20 Year 2008, SMEs is stated to have the principles of kinship, democracy of economiy, togetherness, fairness efficiency, sustainable, environmentally friendly, independence, balance of progress, and national economic integration. SMEs aims to grow and develop business in the framework of national economic development based on equal economic democracy.

There are several obstacles faced by the SMEs in accessing the financial institutions. Based on the study results conducted by Bank Indonesia, it is concluded that the SMEs have the obstacle to access and to obtain the funding resources from banks. This is due to the low knowledge on how to manage the business, especially on the financial aspects (Bank Indonesia, 2012). Various studies conducted in various countries also prove that financial problem is the most urgent problem faced by small business (Thevaruban, 2009; Suwastika \& Anand, 2012)

Generally, the financial problems faced by the SMEs are due to the low financial ability or competency of the small business player (Rose, Kumar, \& Yen, 2006). The low financial competencies is shown in the low financial literacy of small business player. Financial literacy is one of the principles that reflects conducive conditions which encourage access to financial institutions or financial inclusion (G20, 2012). Financial literacy will also affect the performance of small businesses (Dahmen \& Rodríguez, 2014).

\section{CONCEPTUAL FRAMEWORK}

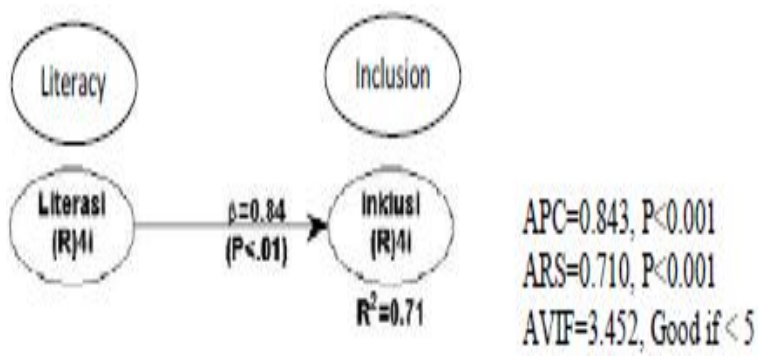

Figure 1: Research Framework and Result

This study highlights the level of financial literacy by measuring four indicators, namely: Basic Knowledge of Financial Management, Credit Management, Savings and Investment Management, Risk Management (Chen \& Volpe, 1998). Financial inclusion is measured using four indicators, namely: availability / access, usage, quality, and welfare (Setiawan, 2015). This research finds out the correlation between financial literacy and financial inclusion, and then analyze the factors that hinders the development of financial inclusion. The 

of Handicrafts Business in West Sumatera

conceptual framework and results can be seen in Figure 1 as follows:

Hypothesis: Financial literacy has a positive effect on the financial inclusion of the handicraft SMEs in West Sumatra

\section{IV.RESEARCH METHODS}

The population of this research is all of the hand and machine embroidery craft SMEs in West Sumatera. Samples were taken by purposive area sampling with the criteria of SMEs domiciled in Padang, Pariaman, and Bukittinggi, have a sustainable business, and are in the business for more than three years. The study was conducted on 100 SMEs of hand and machine embroidery crafts as the sample. Primary data were collected through questionnaire and face-to-face interview with respondents, and data collection technique was through indepth-interview and questionnaire. The research results would be generalized better if the research uses a survey method (Kerlinger \& Lee, 2000). The analysis technique used was qualitative descriptive and inductive analysis using PLS (Partial Least Square). PLS is a model of Structural Equation Modeling (SEM) which is based on the variance analysis. Total respondents achievement was measured with Likert scale (Jamieson, 2004). This technique is a powerful method because it is not based on assumptions (Abdillah \& Yogiyanto, 2015).

\section{RESULTS AND DISCUSSION}

\section{Data Description}

\section{Financial Literacy}

Based on money management, credit and debt, saving and investment, and risk management variables, the level of financial literacy of the handicraft SMEs could be identified from the value of respondents achievement (mean) of each research variable. The result is as follows:

\begin{tabular}{|l|l|l|l|l|}
\hline No & Financial I iteracy Variahle & Mean & Percent & Description \\
\hline 1 & Money Management & 3,45 & 69,0 & sufficient \\
\hline 2 & Credit \& Debt Management & 3,13 & 62,6 & sufficient \\
\hline 3 & Saving ami Investment & 2,32 & 56,4 & $\begin{array}{l}\text { Less } \\
\text { sufficient }\end{array}$ \\
\hline 4 & Risk Management & 3,01 & 60,0 & sufficient \\
\hline & Average & 3,10 & 62,0 & sufficient \\
\hline
\end{tabular}

Table 1. Data Recapitulation of Financial Literacy

Source : Primary Data Processing (2017)

From Table 1 above, it can be seen that the samples' ability to manage finance, loans, and risk management is categorized as sufficient, while the ability to manage savings and investments is categorized as less sufficient. Overall, the financial literacy of handicraft entrepreneurs is categorized as sufficiently literate with an average score of 3.10. This indicates that the handicraft entrepreneurs have sufficient knowledge and belief towards financial service institutions and financial products and services, including features, benefits and risks, rights and obligations related to financial products and services.

\section{Financial Inclusion}

The entrepreneurs's perception towards financial inclusion based on access, usage, quality, and welfare, could be identified based on the value of the respondent achievements (mean) of each research variable. The result is as follows:

\begin{tabular}{c|l|ll|l|}
\hline No & Financial Inclusion Variables & Mean & Percent & Description \\
\hline 1 & Access & 3,18 & 63,6 & sufficient \\
\hline 2 & Usage & 2,96 & 59,2 & $\begin{array}{l}\text { less } \\
\text { sufficient }\end{array}$ \\
\hline 3 & Quality & 3,03 & 60,1 & sufficient \\
\hline 4 & Welfare & 3,08 & 61,6 & sufficienl \\
\hline 5 & Average & 3,06 & 61,2 & sufficient \\
\hline
\end{tabular}

Table 2. Data Recapitulation of Financial Inclusion

Source : Primary Data Processing (2017)

Table 2 above shows that the average respondents' perception on financial inclusion policy is categorized as sufficient, and the use of financial institutions belongs to the less sufficient category. There are several obstacles / barriers faced by SMEs in using banking services, as shown in Figure 2 below:

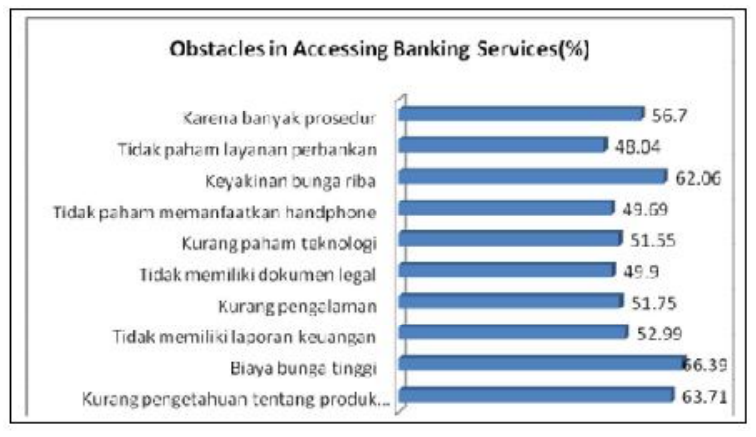

Figure 2: Obstacles faced by handicraft SMEs in accessing banking services

- Too many procedures

- No knowledge of banking services

- A belief that interest is riba (usury)

- Not able to use mobile phones to access lle ser vice

- Tcchnology illitcracy

- Not having legal documents

- Tack of experience

- Not having financial reports

- Iligh cost of interest

- Lack of knowledge about banking products

Based on the Figure 2, there are several factors that hinder the access to banking services, which are: 1) 
high cost of interest, 2) lack of knowledge about banking products, 3) a belief that interest is riba (usury), 4) too many procedures, 5) not having financial reports, 6) lack of experience, 7) technology illiteracy, 8) not having legal documents, 9) not able to use mobile phones to access the service, and 10) no knowledge of banking services.

\section{DISCUSSION}

The financial literacy affects the financial inclusion of the handicraft SMEs in West Sumatra. From the study results, 71 percent of the increase in financial inclusion is influenced by the level of the financial literacy of the entrepreneur. This result is in line with the opinion expressed by $(\mathrm{G} 20,2012)$, who states that financial literacy can stimulate access towards financial institutions or financial inclusion. Therefore, in the framework for developing the financial inclusion, it will be necessary to increase the financial literacy by improving the knowledge about 1) financial management, including financing (budgeting / budget plan), implementation, and evaluation; 2) credit management, so that the credits are used effectively and efficiently as stated in the initial purpose of credit from before the credit is submitted until it is fully paid; 3) savings and investment management, in order to have an easy access to liquidity, financial planning and security; and 4) risk management, a structured and systematic process of identifying, measuring, mapping, developing risk management alternatives, monitoring and controlling risk management, which aims to avoid or to minimize emerging risks. Furthermore, an increase in financial inclusion could happen by directing the handicraft SMEs to use the services of financial institutions.

\section{CONCLUSION}

The results show that the level of financial literacy is categorized as sufficiently literate and the SMEs perception towards the policy of financial inclusion is categorized as sufficiently good. Despite many SMEs still being unfamiliar with formal financial institutions, especially about the services, the factors that hinder the handicraft SMEs in accessing financial services are concluded as follows : 1) high cost of interest, 2) lack of knowledge about banking products, 3) a belief that interest is riba (usury), 4) too many procedures, 5) not having financial reports, 6) lack of experience, 7) technology illiteracy, 8) not having legal documents, 9) not able to use mobile phones to access the service, and 10) no knowledge of banking services.

\section{REFERENCES}

[1] Abdillah, W., \& Yogiyanto. (2015). Partial Least Square (Pls): Alternatif Structural Modelling. Yogyakarta: Andi Publisher.
[2] Alamsyah, H. (2014). Pentingnya Keuangan Inklusif dalam Meningkatkan Akses Masyarakat dan UMKM terhadap Jasa Keuangan Syariah. Surabaya: Seminar Keuangan Inklusif.

[3] Bank Indonesia. (2012). Booklet Keuangan Inklusif. Jakarta: Departemen Pengembangan Akses Keuangan dan UMKM Bank Indonesia.

[4] Bank Indonesia, D. (2015). Peningkatan Akses Pembiayaan Bagi Industri Kreative di Indonesia. Indonesia: Bank Indonesia.

[5] Chen, H., \& Volpe, R. P. (1998). An Analysis of Personal Financial Literacy Among College Students. Financial Services Review, 7(2), 107-128.

[6] Dahmen, P., \& Rodríguez, E. (2014). Financial Literacy and the Success of Small Businesses: An Observation from a Small Business Development Center. Numeracy, 7(1), Article 3.

[7] G20. (2012). Financial Inclusion Indicators. Soul: The Global Partnership for Financial Inclusion (GPFI).

[8] Hap. (2017). Pemprov Sumbar Berharap Bank Tingkatkan Kredit UMKM. Indonesia: Moneter.

[9] Huston, S. J. (2010). Measuring Financial Literacy. The journal of Consumer Affairs, 44(2), 296-316.

[10] Jamieson, S. (2004). Likert scales: how to (ab)use them. " Medical Education, 1217-1218.

[11] Kemenkop, K. (2013). Narasi Statistik. Jakarta: www.depkop.co.id.

[12] Keown, \& Anne, L. (2011). The Financial Knowledge of Canadians. Ottawa: Statistics Canada.

[13] Kerlinger, F. N., \& Lee, H. B. (2000). Foundations of behavioral research (4 ed.). Newyork: Holt, NY: Harcourt College Publishers.

[14] Mahdzan, Shahnaz, N., Tabiani, \& Saleh. (2013). The Impact of Financial Literacy on Individual Saving : An Explonatory Study in Malaysian Context. Transformation in Business and Economic, 12(1), 4155.

[15] Mandel, L. (2008). The Financial Literacy of Youth American Adults. University of Washington and Aspen Institute: Amerika.

[16] Muraga, K. P., \& John, N. (2015). Effect of Financial Literacy on Performance of Youth led Entreprises . International Journal of Science Management Entrepreneurship:A case of Equity Group Fundation Training Program in Kiambu, 218-231.

[17] Nidar, S. R., \& Bestari, S. (2012). Personal Financial Literacy Among University Students. World Journal of Social Sciences, 2(4), 162-171.

[18] Rakhmindyarto, \& Syaifullah. (2013). Bunga Rampai Pemikiran Ekonomi Hijau dan Keuangan Inklusif. http://www.kemenkeu.go.id/en/node/42978.

[19] Rose, Kumar, \& Yen. (2006). The dynamics of entrepreneurs' success factors in influencing venture growth. The Journal of Entrepreneurship and Sustainability, 1-19.

[20] Rose, R. C., Kumar, N., \& Yen, L. L. (2006). Entrepreneurs Success Factors and Escalation of Small and Medium-Sized Enterprices in Malaysia. Journal of Social Science, 2(3), 74-80.

[21] Sachindra. (2013). Need for Financial Inclusion and Challange ahead. IOSR Journal of Business and Management (IOSR-JBM), 33-36.

[22] Setiawan, M. A. (2015). Analisis keterkaitan inklusi keuangan terhadap perilaku keuangan personal masyarakat di wilayah kota dan kabupaten Provinsi Jawa Timur. Jurnal Fakultas Ekonomi dan Bisnis, 3(2).

[23] Shankar, S. (2013). Financial Inclution in India: Do Microfinance Institutions AAddress Access Barriers? Journal of Entrepreneurshio Perspective, 2(1), 60-74.

[24] Soepardi, H. S. (2016). UMKM dibayangi kemunduran tanpa literasi keuangan. Jakarta: ANTARA News.

[25] Sugiarto, A. (2013). Implementasi Strategi Nasional Literasi Keuangan Indonesia. Jakarta: Otoritas Jasa Keuangan (OJK). 
Analysis of Financial Literacy and Financial Inclusion as a Strategy to Improve the Competitiveness of Small-Medium Enterprises (SMES) of Handicrafts Business in West Sumatera

[26] Suwastika, N., \& Anand, C. (2012). A Comparative Study of the Financial Problems Faced by Micro, Smal, and Medium Enterprises in Manufacturing of Fiji and Tonga. International Journal of Emerging Market, 7(3), 245-262.

[27] Thevaruban, J. S. (2009). Small Scale Industries and Financial Problems in Sri Lanka. Journal of Asia Entrepreneurship and Sustainability, 5(2), 7-20.

[28] Undang-Undang Nomor 20. (2008). Tentang Usaha Mikr, Kecil, dan Menegah. Jakarta: Republik Indonesia.

[29] Xu, Lisa, Zia, \& Bilal. (2012). Financial Literacy around the World : An Overview of the Evidence with Practical Suggestions for the Way Forward. Policy Research Working Papers, 08. 